\title{
Changes in the tawny owl Strix aluco diet along an urbanisation gradient
}

\author{
Jakub Gryz ${ }^{1}$ • Dagny Krauze-Gryz ${ }^{2}$ (D) \\ Received: 6 August 2018 / Accepted: 22 November 2018 /Published online: 10 December 2018 \\ (C) The Author(s) 2018
}

\begin{abstract}
The aim of this study was to describe how the diet of tawny owl changed along an urbanisation gradient. The research was conducted from 2003 to 2011 in central Poland. Pellets were collected in the following zones: the center of Warsaw, capital city of Poland (inhabited by approximately 2 million people), its outskirts and rural areas beyond the city. To investigate the differences in the percentages of the main groups of prey between the three zones, a redundancy analysis (RDA) method was implemented using CANOCO software. Sparrows, rats, pine voles and striped field mice were most connected to the city center, whereas voles (all species pooled together), northern birch mice, hazel dormice and insects were more commonly found among prey items collected in rural areas. As the outskirts were transitional areas where different habitats typical for both rural areas (such as forest complexes) and urban areas (such as parks or built-up areas) were present, no prey group was strongly connected to this landscape. Mammals were dominant in the diet in winter in all habitat types. Their share ranged from $52 \%$ (in the city center) to approximately $90 \%$ in the outskirts and rural areas. Birds, amphibians, reptiles and insects were more frequent in summer. Overall, the study confirmed high plasticity of the species as an opportunistic predator and its ability to adapt to long-term changes in its main prey in most urbanized areas.
\end{abstract}

Keywords Warsaw $\cdot$ City center $\cdot$ Outskirts $\cdot$ Rural areas $\cdot$ Niche breath $\cdot$ Winter and summer diet

\section{Introduction}

The tawny owl Strix aluco Linnaeus, 1758 managed to colonise almost all terrestrial habitats within its range thanks to its high flexibility in choice of nesting sites, moderate anthropophobia and ability to hunt for a wide range of prey (Cramp 1985). The tawny owl is the most numerous owl species in Poland (Tomiałojć and Stawarczyk 2003) as well as in Europe (Petty and Saurola 1997); it can adapt to life in habitats highly transformed by humans, such as city agglomerations (Cramp 1985; Galeotti et al. 1991; Goszczyński et al. 1993). At present, the tawny owl is one of few owls

Dagny Krauze-Gryz

dagny.krauze@wl.sggw.pl

Jakub Gryz

j.gryz@ibles.waw.pl

1 Department of Forest Ecology, Forest Research Institute, Braci Leśnej 3, 05-090 Raszyn, Poland

2 Department of Forest Zoology and Wildlife Management, Warsaw University of Life Sciences - SGGW, Nowoursynowska 159, 02-776 Warsaw, Poland that nests in downtown areas of cities in central Europe. The diet composition of tawny owls has been the topic of many studies (e.g., Southern 1954; Petty 1999; Sunde et al. 2001; Solonen and Karhunen 2002); however, all of those studies were carried out in wooded or agricultural areas. Urban populations of tawny owls have been relatively rarely studied. The diet composition of the tawny owl in urban areas was analysed in just a few papers (Wendland 1980; Galeotti et al. 1991; Goszczyński et al. 1993; Zalewski 1994; Grzędzicka et al. 2013). Thus far, studies carried out in cities have shown that tawny owls mostly prey upon birds, particularly sparrows (Passer spp.) (Harrison 1960; Schnurre 1961; Baven 1964; Bogucki 1967; Goszczyński et al. 1993; Wendland 1980; Zalewski 1994; Ranazzi et al. 2001). However, a study from south of Poland did not confirm this pattern (Grzędzicka et al. 2013).

In recent decades, most European cities recorded a strong decline in the number of sparrows (review in Wegrzynowicz 2006, 2017). The aim of the present study was to characterise the diet of tawny owl in three areas along an urbanisation gradient - city center, outskirts and rural areas - and show how the diet of urban tawny owls changed when the number of sparrows, their main prey item, dropped severely. 


\section{Material and methods}

\section{Study area}

Most of the materials were collected in the following areas in central Poland: Warsaw, Kampinos National Park and Rogów Forest District. Warsaw is the largest city in Poland and one of the largest cities in central-eastern Europe. Warsaw covers almost $518 \mathrm{~km}^{2}$ and is inhabited by almost 2 million people with a mean population density of 3302 people $/ \mathrm{km}^{2}$. Built-up areas cover approximately $50 \%$ of the whole city, while agricultural areas, forests and water bodies cover $30 \%, 16 \%$ and $3 \%$, respectively (www.um.warszawa.pl). The number of tawny owl pairs within the city was previously assessed at $75-85$ pairs with a density of $1.4-1.6$ pairs $/ 10 \mathrm{~km}^{2}$ (Gryz and Krauze-Gryz 2015). In Warsaw, data were collected in city center and outskirts (15 sites in total). In the first zone, seven districts with the highest population density (minimum 5710 people $/ \mathrm{km}^{2}$ ) that did not border extra-urban areas were included. Remaining districts of lower urbanisation were included in the suburban zone (=outskirts). Tawny owls inhabited parks and cemeteries in both zones, while in the outskirts, pellets were also collected in forests and singlefamily housing areas.

Materials from rural areas were collected in Kampinos National Park. The park borders the Warsaw agglomeration; it has an area of $390 \mathrm{~km}^{2}$ of which forests cover almost $72 \%$. The remaining area contains mostly meadows and pastures. Density of tawny owls in this area was previously estimated to be 3.1-5.2 pairs $/ \mathrm{km}^{2}$ (Żmihorski et al. 2005; Olszewski et al. 2010). The second rural area was Rogów Forest District, which is approximately $70 \mathrm{~km}$ from the edge of Warsaw. This area was characterised by small forest complexes $\left(0.4-10.0 \mathrm{~km}^{2}\right)$ surrounded by agricultural areas (detailed description is given in Goszczyński et al. 2005). Density of tawny owls was previously estimated to be 2.6 pairs $/ 10 \mathrm{~km}^{2}$ (Gryz et al. 2013).

\section{Pellet collection and analysis}

The study was conducted in the years 2003-2011. Pellets were collected in the territories of tawny owls throughout the year and then pooled into the following seasons: spring-summer (April-September) and autumn-winter (October-March). Standard procedures of pellet analysis were applied (Raczyński and Ruprecht 1974; Yalden and Morris 1990). Prey remains were identified with the aid of various keys (Ruprecht 1979; Pucek 1981; Moreno 1985, 1986; Brown et al. 1999; Ruprecht and Kościów 2007). Diet composition was presented as the percent of a given prey item in the total amount of prey. Niche breadth was calculated with the aid of the Simpson formula ( $\mathrm{D}=1 / \sum p_{i}{ }^{2}, p i$-proportion of a given prey in a diet). The degree of niche overlap (C) between seasons in each habitat was assessed using the Morisita index modified by Horn (Morisita 1959; Horn 1966). Additionally, for a study site located in the central part of Warsaw (the Royal Lazienki Park), data from the present study were compared with data from the 1970s (Goszczyński et al. 1993). The park is protected as a national heritage site; thus, no significant changes had taken place within its boundaries. The park covers approximately 80 ha and is located in the central part of the city. Four breeding pairs of tawny owl were recorded within the park area; this number did not change between the two periods (Gryz and Krauze-Gryz 2015).

\section{Statistical analyses}

To investigate differences in the percentages of main groups of prey between the three studied areas (city center, outskirts and rural areas), a redundancy analysis (RDA) method was implemented in CANOCO software. The percentages of the main prey groups were calculated for each site of pellet collection (only samples with more than 10 prey items were included) and separately for spring/summer and autumn/winter seasons, with a total of 17 samples for the city center, 34 for the outskirts and 89 for rural areas. The prey percentages (arcsine transformed) of each prey group were defined as the response variables, whereas the study area served as the explanatory variable. The seasons were included in the analysis as covariates. A Monte Carlo test (499 permutations) was used to test the statistical significance of the differences between the two methods. A chi-square test was used to test differences between seasons and study areas in the percentage share of different groups of prey. Bonferroni adjustment was applied to multiple comparisons.

\section{Results}

\section{Changes in the diet along an urbanisation gradient}

In total, 9796 prey items of tawny owls were identified in the collected material; most were from rural areas, with the fewest in the city center. The lowest share of mammals was in pellets from the city center $(35.3 \%)$. Birds dominated the diet in this area, accounting for almost $60 \%$ of prey items. The share of amphibians was small in all studied zones. Their largest share was in rural areas (7.7\%). Reptiles and fish were sporadically caught by owls. The largest percentage of insects was recorded for rural areas (17.4\%). The broadest food niche was in the outskirts, and the narrowest niche was in the city center (Table 1). The redundancy analysis revealed that the landscape type (city center, outskirts and rural areas) significantly explained the variability in diet composition $(\mathrm{F}=40.350$, $p<0.005,499$ permutations) (Fig. 1). Sparrows, rats Rattus 
Table 1 Prey composition of tawny owl in three studied areas along an urbanisation gradient in central Poland from 2003 to 2011

\begin{tabular}{|c|c|c|c|}
\hline Prey & $\begin{array}{l}\text { City center } \\
\text { Percentage }\end{array}$ & $\begin{array}{l}\text { Outskirts } \\
\text { rence }(\%)\end{array}$ & Rural areas \\
\hline Microtus arvalis (Eversmann, 1841) & & 2.7 & 7.7 \\
\hline Microtus oeconomus (Pallas, 1776) & & 0.6 & 4.2 \\
\hline Microtus agrestis (Linnaeus, 1761) & & & 2.3 \\
\hline Microtus spp. & & 1.2 & 2.1 \\
\hline$\sum$ Microtus & & 4.5 & 16.3 \\
\hline Arvicolinae indet. & & 0.8 & 0.7 \\
\hline Microtus subterraneus (de Selys-Longchamps, 1836) & 3.6 & 0.7 & 0.2 \\
\hline Myodes glareolus (Schreber, 1780) & & 13.0 & 11.2 \\
\hline Arvicola amphibius (Linnaeus, 1758) & & + & 0.2 \\
\hline Apodemus agrarius (Pallas, 1771) & 19.0 & 8.0 & 3.0 \\
\hline Apodemus flavicollis (Melchior, 1834) & & 18.0 & 18.4 \\
\hline Apodemus sylvaticus (Linnaeus, 1758) & & 0.3 & 0.9 \\
\hline Apodemus spp. & 3.4 & 3.8 & 2.9 \\
\hline Mus musculus Linnaeus, 1758 & 1.2 & 1.1 & 1.8 \\
\hline Micromys minutus (Pallas, 1771) & 0.6 & 0.4 & 0.3 \\
\hline Rattus norvegicus (Berkenhout, 1769) & 3.5 & 1.0 & 0.8 \\
\hline Muridae indet. & 0.2 & 1.5 & 0.9 \\
\hline Sciurus vulgaris Linnaeus, 1758 & 0.1 & & + \\
\hline Sicista betulina (Pallas, 1778) & & & 0.5 \\
\hline Muscardinus avellanarius (Linnaeus, 1758) & & & 0.8 \\
\hline$\sum$ Rodentia & 31.6 & 53.1 & 58.9 \\
\hline Sorex araneus Linnaeus, 1758 & & 4.3 & 3.9 \\
\hline Sorex minutus Linnaeus, 1766 & & 1.2 & 0.6 \\
\hline Neomys fodiens (Pendant, 1771) & & & 0.4 \\
\hline Talpa europaea Linnaeus, 1758 & 1.6 & 1.5 & 0.8 \\
\hline$\sum$ Soricomorpha & 1.6 & 7.0 & 5.7 \\
\hline Erinaceus roumanicus Barrett-Hamilton, 1900 & & + & \\
\hline Mustela nivalis Linnaeus, 1766 & 0.0 & 0.1 & 0.1 \\
\hline Neovison vison Schreber, 1777 & & + & \\
\hline Chiroptera & 2.1 & 0.7 & 0.2 \\
\hline$\sum$ Mammalia & 35.3 & 60.9 & 64.9 \\
\hline Passer spp. & 25.4 & 4.0 & 1.2 \\
\hline Other birds & 33.5 & 20.5 & 8.2 \\
\hline$\sum$ Aves & 58.9 & 24.5 & 9.4 \\
\hline Anura & 4.0 & 4.9 & 7.7 \\
\hline Reptilia & & 0.4 & 0.6 \\
\hline Pisces & 0.1 & & \\
\hline Insecta & 1.7 & 9.2 & 17.4 \\
\hline $\mathrm{N}$ & 947 & 2583 & 6266 \\
\hline Nische breath & 2.2 & 2.8 & 2.5 \\
\hline
\end{tabular}

(+- percentage of occurrence below 0.1$) . \mathrm{N}-$ number of prey items spp., pine voles (Microtus subterraneus) and striped field mice (Apodemus agrarius) were most often found in the city center, whereas voles (all species pooled together), northern birch mice (Sicista betulina), hazel dormice (Muscardinus avellanarius) and insects were more commonly found in rural areas. No prey group was strongly connected with outskirts.

\section{Seasonal differences in diet composition}

Diet composition differed significantly between springsummer and autumn-winter seasons in three habitat types (Table 2). Mammals were dominant in the diet in winter for all habitat types. Their share ranged from $52 \%$ (in the city 
Fig. 1 Biplot from redundancy analysis (RDA) showing the influence of the urbanization gradient on the variability in tawny owl diet

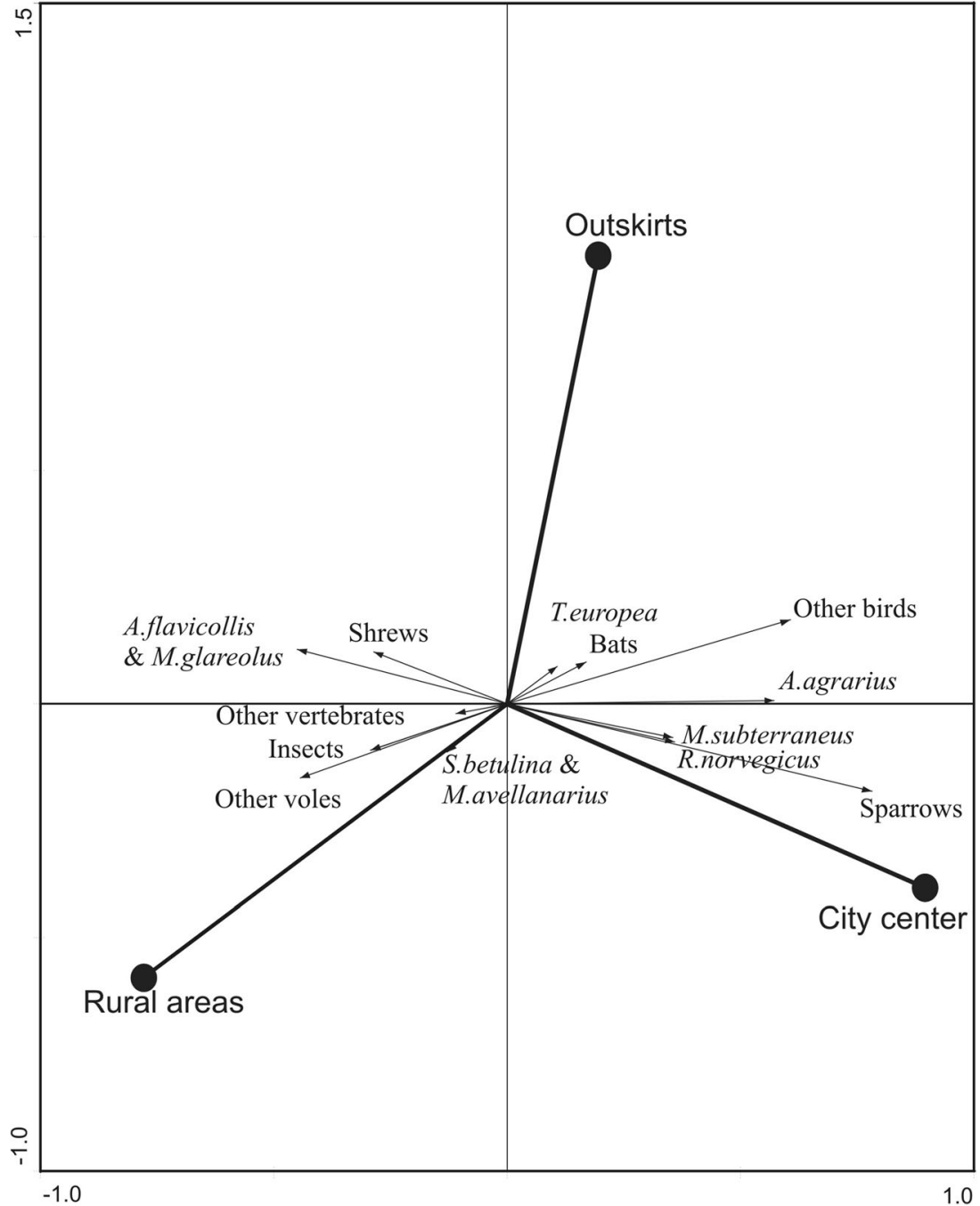

Table 2 Seasonal differences (S - spring/summer, W - autumn/winter) in diet composition of tawny owl along an urbanisation gradient in central Poland from 2003 to 2011

\begin{tabular}{|c|c|c|c|c|c|c|}
\hline \multirow[t]{2}{*}{ Prey } & \multicolumn{2}{|c|}{ City center } & \multicolumn{2}{|c|}{ Outskirts } & \multicolumn{2}{|c|}{ Rural areas } \\
\hline & $\mathrm{S}$ & $\mathrm{W}$ & $\mathrm{S}$ & W & $\mathrm{S}$ & $\mathrm{W}$ \\
\hline Rodentia & 20.9 & 47 & 43.5 & 75.6 & 49.4 & 83.9 \\
\hline Soricomporha & 1.3 & 2.1 & 6.1 & 9.3 & 6.1 & 5.2 \\
\hline Other mammals & 1.8 & 2.6 & 0.9 & 1.2 & 0.4 & 0.2 \\
\hline Mammalia & 23.9 & 51.7 & 50.5 & 86.1 & 55.9 & 89.3 \\
\hline Aves & 68.2 & 45.4 & 30.1 & 11.2 & 10.2 & 7.1 \\
\hline Anura & 5.0 & 2.6 & 6.5 & 0.9 & 9.9 & 1.8 \\
\hline Reptilia & & & 0.6 & & 0.8 & 0.1 \\
\hline Pisces & & 0.3 & 0.1 & & & \\
\hline Insecta & 2.9 & & 12.2 & 1.8 & 23.2 & 1.7 \\
\hline $\mathrm{N}$ & 560 & 387 & 1808 & 775 & 4552 & 1714 \\
\hline Niche breath & 2.0 & 2.3 & 3.3 & 1.7 & 3.1 & 1.4 \\
\hline
\end{tabular}

$\mathrm{N}$ - number of prey items center) to $89 \%$ in outskirts and rural areas (Table 2). On the other hand, birds, amphibians, reptiles and insects were more frequent in summer. Changes in the share of main prey groups between seasons were statistically significant for all zones, except for amphibians in the city center (Table 3 ). In the outskirts and in rural areas, food niche was much wider in springsummer than in autumn-winter. In the city center, niche breadth was similar in both seasons. Niche breadth overlap between seasons was very similar in the three analysed zones (in the city center $\mathrm{C}=0.87$, in the outskirts $\mathrm{C}=0.84$ and in rural areas $\mathrm{C}=0.86$ ).

\section{Long-term changes in the diet of tawny owls from the city center}

Comparison of diet composition based on data from Royal Łazienki Park from 1975 to 1977 and 2004-2008 (Goszczyński et al. 1993; Goszczyński J. unpbl. data) showed a decrease in the share of sparrows from 51.3 to 
Table 3 Differences between spring-summer and autumn-winter in the percentage share of selected prey groups

\begin{tabular}{llll}
\hline Prey & City center & Outskirts & Rural areas \\
\hline Mammalia & 76.75 & 284.98 & 595.71 \\
Aves & 47.39 & 105.58 & 13.23 \\
Anura & $\mathrm{ns}$ & 36.79 & 117.5 \\
Insects & 9.57 & 71.51 & 403.41 \\
\hline
\end{tabular}

Values of a chi-square test are given when significant, $p<0.0125$ (with a Bonferroni's adjustment), ns - non significant. Yates' correction was applied

$27.0 \%$ and an increase in that of striped field mice from $6.1 \%$ to $25.7 \%$ (Table 4 ).

\section{Discussion}

\section{Differences in diet composition along an urbanisation gradient}

Differences in the diet of tawny owls between the three habitat types were similar to results obtained by other researchers. The presence of birds as the dominant prey item in urban habitats has been recorded in different parts of Europe (Harrison 1960; Baven 1964; Bogucki 1967; Ranazzi et al. 2001). The relatively small percentage of birds recorded in the diet of tawny owls from the Apennine Peninsula (Ranazzi et al. 2001), could be a result of zoogeographical differences (the abundance of reptiles in the region bordering the Mediterranean Sea). Mammals are the second most important prey group of tawny owls in cities. In European cities, mammals usually account for less than $35 \%$ of vertebrate prey items (Goszczyński et al. 1993; Zalewski 1994; Ranazzi et al. 2001). Amphibians are a marginal element in the diet of urban tawny owls both in this and in the earlier studies. The decreasing proportion of insects in the diet along an urbanisation gradient was previously demonstrated by Grzedzicka et al. (2013) in southern Poland.

Table 4 Differences in the percentage share of the two main groups of prey/prey species in the diet of tawny owl in the city center of Warsaw (Royal Łazienki Park) between the two periods

\begin{tabular}{llll}
\hline Prey & $1975-1977$ & $2004-2008$ & chi-square \\
\hline Apodemus agrarius & 6.1 & 25.7 & 56.92 \\
Other mammals & 16.6 & 17.5 & $\mathrm{~ns}$ \\
Passer spp. & 51.3 & 27.0 & 48.63 \\
Other birds & 25.8 & 29.8 & $\mathrm{~ns}$ \\
$\mathrm{~N}$ & 423 & 382 & \\
\hline
\end{tabular}

Values of a chi-square test are given when significant, $\mathrm{df}=1, p=0.0125$ (with Bonferroni's adjustment). Yates' correction was applied. $\mathrm{N}$ - number of prey items
Comparison of data from this study and an earlier study (Goszczyński et al. 1993) showed some differences in the diet of tawny owls in the center of Warsaw. The general proportions between main groups of prey were the same (dominance of birds, marginal percentage or absence of amphibians); nevertheless, the percentage of birds decreased, while the percentage of mammals and amphibians increased. Moreover, the observed pattern in the variability of niche breadth was quite different. A previous study recorded a remarkable decrease in niche breadth that correlated with increasing urbanisation, while this study found no difference between the niche breadth of urban and exurban tawny owls. This was due to lower disproportion in the share of birds and mammals in the diet of owls nesting in the center of Warsaw.

A detailed analysis of variability in tawny owl diet along an urbanisation gradient can be found in four studies (Wendland 1980; Galeotti et al. 1991; Goszczyński et al. 1993; Zalewski 1994). All of these studies claim that an increasing proportion of birds in the diet of urban owls is a result of the abundance of house sparrows Passer domesticus (Linnaeus, 1758). Similar to our results, the authors of those previous studies found that the percentage of rodents in the diet decreased with increasing urbanisation. However, the very high percentage of striped field mouse (19\%) found in the city center of Warsaw from 2003 to 2011 was not recorded in earlier studies. Goszczyński et al. (1993) found the highest proportion of striped field mouse in the diet of owls inhabiting forests in suburban areas (approximately $7 \%$ of vertebrate prey). Data from Berlin (Wendland 1980) are very general and do not contain information on the percentage share of Apodemus species. Nevertheless, tawny owls from suburban forest preyed mainly on yellow-necked mice A. flavicollis, which together with other Apodemus species, accounted for $35 \%$ of prey items; in the central zone of Berlin three Apodemus species accounted for only $13.5 \%$. The data from Torun in Poland (Zalewski 1994) show an increasing proportion of striped field mice in the tawny owl diet correlated with an increase in urbanisation level. However, differences between the percentage of this species between the two urban zones were smaller than in our study (1.8\% in the suburban zone and 5\% in the central zone). According to studies from Pavia in Italy, which is beyond the geographical range of striped field mouse (Gliwicz and Kryštufek 1999), wood mouse (Apodemus sylvaticus) was the second rodent according to the percentage share of consumed biomass (5.6\%) (Galeotti et al. 1991).

The high share of rats in the city center in our study is a result of the high density of these mammals in urban areas (Traweger et al. 2006; van Adrichem et al. 2013). On the contrary, northern birch mouse and hazel dormouse are typical species in forest areas; thus, they do not occur in cities (Juškaitis 2007; Lesiński et al. 2009; Balčiauskas et al. 2011; Juškaitis and Buchner 2013). Additionally, voles (Microtus spp.) that typically inhabit open areas do not find suitable habitats in cities (Kostian 1970; Goszczyński 1981; 
Borowski 2003), therefore were mostly found in rural areas. The only exception is European pine vole, which inhabits a wide range of habitats (Innes and Millar 1994; Michel et al. 2007; Amori et al. 2016) and was mostly connected to the city center in our study.

\section{Seasonal differences in the diet}

Most papers that focused on seasonal differences in the diet of tawny owls (Goszczyński 1981; Galeotti et al. 1991; Kirk 1992; Goszczyński et al. 1993; Zalewski 1994; Jędrzejewska and Jędrzejewski 1998; Sunde et al. 2001; Żmihorski and Osojca 2006) showed a higher share of bids and amphibians in warm seasons versus a higher share of mammals in the autumn-winter season, which agrees with results obtained in this study. However, different results were found in two papers (Goszczyński 1981; Sunde et al. 2001). Sunde et al. (2001) found no remains of amphibians in pellets, which could be the result of their low abundance in Norway or a nonrepresentative sample from the summer (32 pellets). In data from western Poland (Goszczyński 1981), comparison between diets in winter and summer showed that in winter, tawny owls preyed on birds more often. This was due to low abundance of common voles (Microtus arvalis, the most important diet component in this area) in winter, which forced owls to search for birds as an alternative prey (Goszczyński 1981). Goszczyński et al. (1993) showed that along gradient of an increasing urbanisation, seasonal differences in the diet of tawny owls became less apparent. In the 1970s, tawny owls in the city center of Warsaw preyed heavily on birds throughout the year. When the population of house sparrow crashed (Węgrzynowicz 2006, 2017), this changed. In present conditions, differences between the diet in the warm and cold seasons were as clear in urban as in rural populations of tawny owl, which is quite different from what was found in Warsaw 30 years ago (Goszczyński et al. 1993).

\section{Long-term changes in diet composition of tawny owls in the city center}

The decrease in the proportion of sparrows in the diet of tawny owl shown in this study is a reaction to lower availability of this prey. In the last 30 years, the abundance of house sparrows in Warsaw declined (Wegrzynowicz 2006, 2017). Similar population declines in this species have also been observed in other European cities (review in Wegrzynowicz 2006). Nevertheless, to the best of our knowledge, there are no studies from these cities that evaluate the diet of tawny owl before and after house sparrow population decline. Functional reaction of tawny owl to changes in prey availability has been shown with forest rodents (e.g., Jedrzejewska and Jedrzejewski 1998). It was also documented for common voles (Goszczyński 1981) and for forest populations of field voles (Microtus agrestis) (Petty 1999). A functional reaction was also recorded by Wendland (1984) for amphibians. Almost 30 years of studies of common spadefoot (Pelobates fuscus (Laurenti, 1768)) in the suburbs of Berlin showed its gradual disappearance from this area and, as a result, its decreasing percentage in the diet of tawny owl. The increase in the consumption of striped field mouse that was found in our study could be a result of lower access to house sparrows, which according to Goszczyński et al. (1993) formed 50\% of prey items in the city center. An additional factor could be its higher abundance in Royal Łazienki Park compared with that during previous periods (Cichocka 2003).

Overall, the study confirmed high plasticity of the species, whose feeding ecology adjusted to various levels of urbanisation but also which reacted to long-term changes in the number of the main prey in the most urbanised areas - city center of Warsaw.

\section{Compliance with ethical standards}

Conflict of interest The authors declare that they have no conflict of interest.

OpenAccessThis article is distributed under the terms of the Creative Commons Attribution 4.0 International License (http://creativecommons.org/ licenses/by/4.0/), which permits unrestricted use, distribution, and reproduction in any medium, provided you give appropriate credit to the original author(s) and the source, provide a link to the Creative Commons license, and indicate if changes were made.

\section{References}

Amori G, Hutterer R, Yigit N, Mitsain G, Kryštufek B, Vohralík V, Zima J, Zagorodnyuk I (2016) Microtus subterraneus (errata version published in 2017) The IUCN Red List of threatened species 2016. http://www.iucnredlist.org/details/13489/0. Accessed 22 July 2017

Balčiauskas L, Balčiauskiene L, Alejunas P (2011) Northern birch mouse Scista betulina in Lithuania, findings in the diet of tawny owl Strix aluco. Acta Zool Hung 57:277-289

Baven G (1964) The food of tawny owls in London. Lond Bird Report 29:56-72

Bogucki Z (1967) O pokarmie puszczyka (Strix aluco L) gnieżdżącego się w śródmieściu Poznania [On the food of the tawny owl (Strix aluco L) nesting in the city center of Poznań]. Przegl Zool 11:71-74

Borowski Z (2003) Habitat selection and home range size of field voles Microtus agrestis in Słowiński National Park, Poland. Acta Theriol 48:325-333. https://doi.org/10.1007/BF03194172

Brown R, Ferguson J, Lawrence M, Lees D (1999) Tracks and signs of the birds of Britain and Europe an identification guide. A\&C Black, London

Cichocka A (2003) Drobne ssaki terenów zielonych Warszawy [Small mammals of green areas in Warsaw]. Master's thesis, Department of Forest Zoology and Wildlife Management, Faculty of Forestry. In: Warsaw University of Life Sciences

Cramp S (ed) (1985) Handbook of the birds of Europe the Middle East and North Africa Vol IV. Oxford University Press, Oxford - New York 
Galeotti P, Morimando F, Violani C (1991) Feeding ecology of the tawny owls (Strix aluco) in urban habitats (northern Italy). Boll Zool 58: 143-150. https://doi.org/10.1080/11250009109355745

Gliwicz J, Kryštufek B (1999) Apodemus agrarius (Pallas 1771). In: Mitchell-Jones AJ, Amori G, Bogdanowicz W, Kryštufek B, Reijnders PJH, Spitzenberger F, Stubbe M, Thissen JBM, Vohralík V, Zima J (eds) The atlas of European mammals. Academic Press, London, pp 266-267

Goszczyński J (1981) Comparative analysis of food of owls in agrocenoses. Ekol Pol 29:431-439

Goszczyński J, Gryz J, Krauze D (2005) Fluctuation of a common buzzard Buteo buteo population in Central Poland. Acta Ornithol 40: 75-78

Goszczyński J, Jabłoński P, Lesiński G, Romanowski J (1993) Variation in diet of tawny owl Strix aluco L along urbanization gradient. Acta Ornithol 27:113-123

Gryz J, Krauze-Gryz D (2015) Występowanie puszczyka Strix aluco na terenie Warszawy w latach 2005-2010 [Occurrence of tawny owl Strix aluco in Warsaw in the years 2005-2010]. Ornis Pol 54:212217

Gryz J, Krauze-Gryz D, Goszczyński J (2013) Występowanie sów Strigiformes na terenie Leśnego Zakładu Doświadczalnego SGGW w Rogowie (środkowa Polska) [Occurrence of owls Strigiformes in the area of Forest Experimental Station of WULSSGGW in Rogów (central Poland)]. Sylwan 157:695-702

Grzędzicka E, Kus K, Nabielec J (2013) The effect of urbanization on the diet composition of the tawny owl (Strix aluco). Pol J Ecol 61:391400

Harrison CJO (1960) The food of some urban tawny owls. Bird Study 7: 236-240

Horn MS (1966) Measurement of "overlap" in comparative ecological studies. Am Nat 100:419-424

Innes DGL, Millar JS (1994) Life histories of Clethrionomys and Microtus (Microtinae). Mammal Rev 24:179-207

Jędrzejewska B, Jędrzejewski W (1998) Predation in vertebrate communities, the Bialowieza primeval Forest as a case study. Springer Verlag, Berlin Heidelberg

Juškaitis R (2007) Peculiarities of habitats of the common dormouse, Muscardinus avellanarius, within its distributional range and in Lithuania: a review. Folia Zool 56:337-348

Juškaitis R, Buchner S (2013) The hazel dormouse. VerlagsKG Wolf, Magdeburg

Kirk DA (1992) Diet changes in breeding tawny owls (Strix aluco). J Raptor Res 26:239-242

Kostian E (1970) Habitat requirements and breeding biology of the root vole Microtus oeconomus (Pallas) on shore meadows in the Gulf of Bothnia, Finland. Ann Zool Fenn 7:329-340

Lesiński G, Błachowski G, Siuchno M (2009) Vertebrates in the diet of the tawny owl Strix aluco in northern Podlasie (NE Poland) - comparison of forest and rural habitats. Fragm Faun 52:51-59

Michel N, Burel F, Legendre P, Butet A (2007) Role of habitat and landscape in structuring small mammal assemblages in hedgerow networks of contrasted farming landscapes in Brittany, France. Landsc Ecol 22:1241-1253. https://doi.org/10.1007/s10980-0079103-9

Moreno E (1985) Clave osteologica para la identification de los Passeriformes Ibericos 1 Aegithalidae, Remizidae, Fringiliade, Alaudidae. Ardeola 32:295-377

Moreno E (1986) Clave osteologica para la identification de los Passeriformes Ibericos 2 Hirundinidae, Prunellidae, Sittidae, Cerothidae, Troglotytidae, Cinclidae, Lanidae, Oriolodae, Corvidae, Sturnidae, Motacillidae. Ardeola 33:69-129

Morisita M (1959) Measuring of interspecific association and similarity between communities. Mem Fac Sci Kyushu Univ Series E 3:65-80
Olszewski A, Woźniak B, Chodkiewicz T, Lewtak J (2010) Sowy Strigiformes środkowej części Kampinoskiego Parku Narodowego [Owls Strigiformes of central part of Kampinos National Park]. Ornis Pol 51:252-261

Petty SJ (1999) Diet of tawny owls (Strix aluco) in relation to field vole (Microtus agrestis) abundance in conifer forest in northern England. J Zool 248:451-465

Petty SJ, Saurola P (1997) Tawny owl Strix aluco. In: Hagemaier WJM, Blair MJ (eds) The European bird census council atlas of European breeding birds. T and A D Poyser, London, pp 410-411

Pucek Z (ed) (1981) Keys to vertebrates of Poland - mammals. Polish Scientific Publishers, Warsaw

Raczyński J, Ruprecht AL (1974) The effect of digestion on the osteological composition of owl pellets. Acta Ornithol 14:25-36

Ranazzi L, Manganaro A, Salvati L (2001) Notes on the diet of successful and failed breeding tawny owls (Strix aluco) in urban Rome. Italy Acta Zool Cracov 44:53-57

Ruprecht AL (1979) Kryteria identyfikacji gatunkowej podrodzaju Sylvaemus Ognev and Vorobiev, 1923 (Rodentia: Muridae) [Criteria for species identification of subgenus Sylvaemus Ognev and Vorobiev, 1923 (Rodentia: Muridae)]. Przegl Zool 23:340-350

Ruprecht AL, Kościów R (2007) Taksonomiczna wartość zębów u rodzaju Rattus Fischer, 1803 (Rodentia: Muridae) [Taxonomic values of teeth in Rattus Fischer, 1803 (Rodentia: Muridae)]. Przegl Zool 51:189-198

Schnurre O (1961) Lebensbilder märkischer Waldkäuze (Strix aluco L). Milu 1:83-124

Solonen T, Karhunen J (2002) Effect of variable feeding condition on the tawny owl Strix aluco near the northern limits of its range. Ornis Fenn 79:121-131

Southern HN (1954) Tawny owls and their prey. Ibis 96:384-410

Sunde P, Overskaug K, Bolstad JP, Øien IJ (2001) Living at the limit: ecology and behaviour of tawny owls Strix aluco in a northern edge population in Central Norway. Ardea 89:495-508

Tomiałojć L, Stawarczyk T (2003) Awifauna Polski - rozmieszczenie, liczebność i zmiany [Polish Avifauna - distribution, abundance and changes]. Polskie Towarzystwo Przyjaciół Przyrody ,pro Natura", Wrocław

Traweger D, Travnitzky R, Moser C, Walzer C, Bernatzky G (2006) Habitat preferences and distribution of brown rat (Rattus norvegicus Berk) in city of Salzburg (Austria): implications for an urban rat management. J Pest Sci 79:113-125. https://doi.org/10.1007/ s10340-006-0123-z

van Adrichem MHC, Buijs JA, Goedhart PW, Verboom J (2013) Factors influencing the density of the brown rat (Rattus norvegicus) in and around houses in Amsterdam. Lutra 56:77-91

Wegrzynowicz A (2006) Changes in number of the house sparrow (Passer domesticus) and tree sparrow (Passer montanus) in Warsaw, Poland, during 1971 - 2006. Int Stud Sparrows 31:13-26

Węgrzynowicz A (2017) Breeding parameter changes in two syntopic urban sparrow species with contrasting population trends. Orn Fenn 94:113-124

Wendland V (1980) Der Waldkauz (Strix aluco) im bebauten Stadtgebiet von Berlin (West). Beitr Vogel 26:157-171

Wendland V (1984) The influence of prey fluctuations on the breeding success of the tawny owl Strix aluco. Ibis 126:284-295

Yalden DW, Morris PA (1990) The analysis of owl pellets. Mammal Society Occasional Publication, 13 London

Zalewski A (1994) Diet of urban and suburban tawny owls in the breeding season. J Raptor Res 28:246-252

Żmihorski M, Osojca G (2006) Diet of the tawny owl (Strix aluco) in the Romincka Forest (NE Poland). Acta Zool Lit 16:46-52

Żmihorski M, Krupiński D, Osojca G, Jarzombkowski F (2005) Sowy Strigiformes wschodniej części Kampinoskiego Parku Narodowego. Kulon 10:43-46 